\title{
Antecedent of lack of proficiency and the need for an automated financial plan for the course entrepreneurship creativity and innovation
}

\author{
Mohammed Muneerali Thottoli \\ University of Nizwa, Nizwa, Oman
}

Antecedent of lack of proficiency

\begin{abstract}
Purpose - This study aims to analyze antecedents of students' lack of proficiency (in preparing financial statements, cash flow statements, cost volume profit analysis and budgeting) and the need for an automated financial plan (AFP) for the course entrepreneurship creativity and innovation within Higher Educational Institutions (HEIs) in Oman.

Design/methodology/approach - The study used a set of four instrument items containing questionnaires to measure the variables in this study. A cross-sectional study was carried out at various universities and colleges in Oman during the year 2020, comprising 174 students from different majors. The results were analyzed using structural equation modelling-partial least squares.

Findings - The findings of the study suggest that the students in the universities and colleges should be educated and facilitated to enable them to gain more knowledge in finance/accounting through an AFP and, thus, warrants preparation of fair financial estimation for their innovative business project. A majority of students strongly support the need for implementing an AFP for their compulsory course, entrepreneurship creativity and innovation in HEIs in Oman.
\end{abstract}

Research limitations/implications - This research is restricted to AFPs for the students in Oman who study the course entrepreneurship creativity and innovation. It is recommended that future study may extend to automated business plans for the students to improve their practical knowledge pertinent to the readiness of Omani students, as well as to give material transformation of internal environments in HEIs.

Practical implications - Unique AFP for university and college students for their compulsory course, entrepreneurship creativity and innovation provide important resources for policymakers responsible for HEIs, allowing them to improve the quality of preparing a financial plan for their innovative business ideas and new business start-ups.

Originality/value - There has been little discussion about the need for an AFP for the students who study the course entrepreneurship creativity and innovation. This study analyzes accounting standards as antecedents about students' lack of proficiency towards an AFP for the course entrepreneurship creativity and innovation of universities and colleges in Oman which tries to fill this gap in the existing research. Hence, this study is considered as a novel approach that has not been broadly discussed in the earlier research.

Keywords Oman, Automated financial plan, Entrepreneurship creativity and innovation, University, College, Curricula

Paper type Research paper

(C) Mohammed Muneerali Thottoli. Published in Journal of Ethics in Entrepreneurship and Technology. Published by Emerald Publishing Limited. This article is published under the Creative Commons Attribution (CC BY 4.0) licence. Anyone may reproduce, distribute, translate and create derivative works of this article (for both commercial and non-commercial purposes), subject to full attribution to the original publication and authors. The full terms of this licence maybe seen at http://creativecommons.org/licences/by/4.0/legalcode

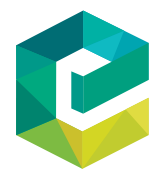

Journal of Ethics in Entrepreneurship and Technology Vol. 1 No. 1, 2021 pp. $61-76$ Emerald Publishing Limited 2633-7436 DOI 10.1108/JEET-04-2021-0015 


\section{JEET 1,1}

\section{Introduction}

Globally, there are several individuals with an entrepreneurial spirit possessing a lot of creativity and innovation. But unfortunately, their innovative business fails spectacularly at an early stage (Lee and Chiravuri, 2019). Execution of a thoughtful and well-organized business plan provides firm support for the success of their entrepreneurship (Tipu, 2019). A typical business plan generally includes marketing, operational, human resource and financial plan. Among them, finance is the lifeblood of any organization. A financial plan provides financial projections for several years which includes profit or loss, cash inflows, cash outflows, affairs of a business, sources and utilization of fund, cost volume profit (CVP) analysis, payback period and break-even point (Ferreras-Garcia et al., 2019). A comprehensive financial plan facilitates every prospective entrepreneur to make their dream a reality. Emerging countries such as Oman, as part of their economic diversification, promote aspired young entrepreneurs to start up their entrepreneurship which creates innovation, creativity, self-efficiency and job creation among themselves. Recently, the Ministry of Higher Education in Oman through various colleges and universities, made the course "entrepreneurship creativity and innovation" compulsory for all the major students who had registered either diploma or bachelor.

The core intention of the course, entrepreneurship creativity and innovation is to motivate and promote innovation and creativity among Omani youths to set up their entrepreneurship and not to prepare a financial plan. There is a lack in examining the students' proficiency towards an automated curriculum-based financial plan for the course entrepreneurship creativity and innovation in Oman. This course has been made compulsory for both accounting and non-accounting undergraduate students. Being accounting is a separate discipline, which requires systematic recording of accounting transactions by Generally Accepted Accounting Principle as well accounting standards, it is difficult for them to understand and prepare a projected financial plan for their proposed business plan. Lack of practical knowledge to prepare financial plans among accounting or non-accounting students is a major constraint to know the viability of their proposed innovative business. Notably, most non-accounting major students have never got an opportunity to study any accounting course before choosing their compulsory course, entrepreneurship creativity and innovation. Another major constraint among students is of lacking practical knowledge of preparing financial plans using technology tools such as MS Excel. Financial projection helps to forecast the income statement, balance sheet, cash flow statement (CFS) and other related reports for more than 1 year (Barrow et al., 2018). Further, the knowledge of accounting standards is considered an antecedent to prepare fair financial statements. Widodo et al. (2019) proposed to study the antecedent of financial statements. An automated financial plan (AFP) provides helps students to generate an AFP for several years with minimum input. Therefore, a lack of knowledge in preparing thoughtful, scientific, alternative income level projected financial plan, leads to spoiling the dream of starting their innovative businesses among Omani youths.

The above set of constraints and problems represents a call for researchers to study to analyze antecedents of students lack of proficiency (LOP) (in preparing financial statements, CFS, CVP analysis and budgeting) and the need for an AFP for the course entrepreneurship creativity and innovation within Higher Educational Institutions (HEIs) in Oman.

The paper is organized as follows. Section 2 provides a literature review. Research methodology is presented in Section 3, The results of the study are given in Section 4. The discussions, conclusions and implications of the study are presented in Sections 5, 6 and 7, respectively. 


\section{Literature review: antecedent of lack of proficiency}

Thorough knowledge of applicable accounting standards, concepts and assumptions are required to prepare fair financial statements including CFS, CVP analysis and budgeting. Thus, LOP in accounting standards and concepts (considered as an antecedent) significantly affect LOP in preparing financial statements, CFS, CVP analysis and budgeting.

\subsection{Proficiency in preparing financial statements}

Although the purpose of non-accounting students was not for accounting, it was for them as obligatory to know the strong professionalism of accounting, they confronted learning the concept of accounting a great difficulty (Huang and $\mathrm{Si}$, 2019). Several non-accounting majors carry concerns about not having past accounting experience both in theory and practical, negative experiences or LOP in preparing financial statements (McCaster, 2020). Nasu et al. (2019) contended that student's perception and proficiency in preparing projected financial statements using information technology are similar irrespective of their major, accounting or non-accounting. Through the integration of artificial intelligence-based accounting software, increases financial statement preparers proficiency that supports functions of account payables, operational tasks and account receivables become easy and efficient (Lee and Tajudeen, 2020; Muneerali, 2020; Thottoli, 2020; Thottoli et al., 2019a, 2019b, 2019c; Thottoli, 2021; Thottoli and Thomas, 2020). Financial statement preparers should have proficiency in tax knowledge, calculation and its effect on financial statements in the digital economy (Bornman and Wassermann, 2020). Accounting using information communication technology (ICT) helps increasing student's proficiency in preparing financial statements (Das and Singh, 2018). AFP facilitated non-accounting students to increase understanding in preparing projected financial statements, though they do not have proficiency in preparing financial statements (Shamsudin et al., 2020). Farrelly et al. (2018) have described a new faculty-student collaborative curriculum-mapping method by establishing an accounting software program for curriculum review consistent with the Certified Public Accountant (CPA) blueprints that can assist both accounting and non-accounting majored students. Hence, it is hypothesized as follows:

H1. Antecedent of lack of proficiency in preparing financial statements has a significant relationship with AFP.

\subsection{Proficiency in preparing cash flow statement}

Many faculties address the two methods of preparing CFSs, direct or indirect method separately, necessitating students to learn the two ways for preparing the operating section. On account of this focus on the procedure of preparation, the result is often important on how to make CFS instead of on the important information the statement provides (Stice et al., 2019). The students under accounting major have not understood how to prepare a CFS well (Sulindawati and Meitriana, 2019). Aspects like preparing reliable financial statements, CFSs, budgeting had a significant influence on students who study entrepreneurship courses (Al Hussaini, 2019). Students lack proficiency and are not adequately trained in financial management, which might cause difficulties in preparing CFSs for their proposed entrepreneurship business activities (Arpat et al., 2019). The skills to perform accurate calculations and preparation of CFS, a basic foundation of financial proficiency affect financial decision making (Donleavy et al., 2018). The ICT financial plan should comprise cash automated calculation of cash flows (Mavl, utova et al., 2019a).
Antecedent of lack of proficiency $+2$ 


\section{JEET 1,1}

Automated cash flow system highly effective for use in the student's learnings process (Sulindawati and Meitriana, 2019). Hence, it is hypothesized as follows:

H2. Antecedent of lack of proficiency in preparing CFS has a significant relationship with AFP.

\subsection{Proficiency in preparing cost volume profit analysis}

Entrepreneurs must run a break-even analysis using the CVP model to know the viability of entrepreneurship businesses (Allen, 2020). Automated application of the CVP analysis helps to provide information to the students and managers at public universities to make the correct decisions (Le et al., 2020). CVP analysis helps foresee problems and improved understanding the financial performance (Cescon and Grassetti, 2020). Okpala and Osanebi (2020) found that sage of CVP analysis on profit planning among entrepreneurs as a means to solve problems such as inability to earn a sustainable income for business continuity problem. Microsoft dynamics can assist hands-on learning CVP to enhanced learning outcomes both functionally and technically (Zadeh et al., 2020). Successful implantation of complete functional (ICT enabled) software application boosts students' skills and knowledge and finally encourages the successful building of knowledge over the process of entrepreneurial innovation. Students from various disciplines showed higher confidence levels on ICT-enabled financial statements to prepare and compare CVP analysis and breakeven analysis (Banerjee et al., 2018; Ahmed et al., 2020; Alabdullah et al., 2019). Business start-ups used CVP ignorantly and have suggested that ICT-enabled CVP analysis, breakeven analysis and such other accounting tools to be introduced among young aspirant entrepreneurs so that improve productivity (Abdullahi et al., 2017). Hence, it is hypothesized as follows:

H3. Antecedent of lack of proficiency in preparing CVP has a significant relationship with AFP.

\subsection{Proficiency in preparing budgeting}

Entrepreneurs should also have proficiency in preparing flexible budgets and budget control. An accurate flexible budget will assist entrepreneurs to determine the success of their business (Ali et al., 2018). Burgos et al. (2020) examined LOP in preparing capital budgeting decision-making among aspirant entrepreneurs and small business owners. The endogenization of budget guidelines is a central element of institutional entrepreneurship (Ahrens and Ferry, 2018). Proficiency in budgeting and fund rising helps entrepreneur's small business enterprises to succeed and grow their entrepreneurial ventures (Nso, 2020). Proficiency in combining smart tools for preparing flexible budgets increases the adoption of ICT practices among entrepreneurs (Karanović et al., 2019). Fakhrurraji et al. (2019) found that there was a problem that occurs at the budgeting stage and provides strategic steps for solving the problem using technology. Automation in budgeting system using Systems Applications and Products in Data Processing enhanced budgeting proficiency among entrepreneurs (Ishmuradova et al., 2019). Computerized accounting for budgeting is a prominent catalyst in promoting aspirant entrepreneurs to ensure the efficiency of their financial management (Ahmad et al., 2018). Entrepreneurs using integrated accounting information technology software for budgeting provide benefits beyond traditional accounting (Fordham and Hamilton, 2019). Hence, it is hypothesized as follows: 
H4. Antecedent of lack of proficiency in preparing budgeting has a significant relationship with AFP.

Accordingly, the theoretical framework has established as shown in Figure 1.
Antecedent of lack of proficiency

\section{Methodology}

This research study has considered designing and develop a quantitative method to assess a set of variables. To conduct the proposed model and testing the hypothesis, the study has used Partial least squares (PLS) analysis. The PLS method provides researchers to evaluate structural path coefficients and measurement model parameters concurrently (Chin, 1998). While considering covariance-based structural equation modeling (SEM), PLS emphasizes the variance of dependent variables explained by independent variables on behalf of replicating the empirical covariance matrix (Haenlein and Kaplan, 2004). PLS analysis model accepts a small sample size to validate the model and provide more stable results than SEM (Barclay et al., 1995). PLS entails ten times the highest sum of independent variables as its sample size affecting a dependent variable or the highest sum of formative indicators (Chin, 1998). In the current study, the highest number of estimated independent variables used for the dependent variables are four. Thus, the selected sample size of 174 comfortably meets the requirements for PLS analysis. The antecedents of LOP in accounting standards and other LOP among students to know the need for an AFP are tested using SEM.

\subsection{Reliability and validity}

It is required to evaluate the accuracy of the path estimates happen to be "true" effect (Chin et al., 1996). According to Nunnally (1978), the reliability test and validity test are necessary psychometrics to be informed. Generally, the estimates of the structural paths are likely to

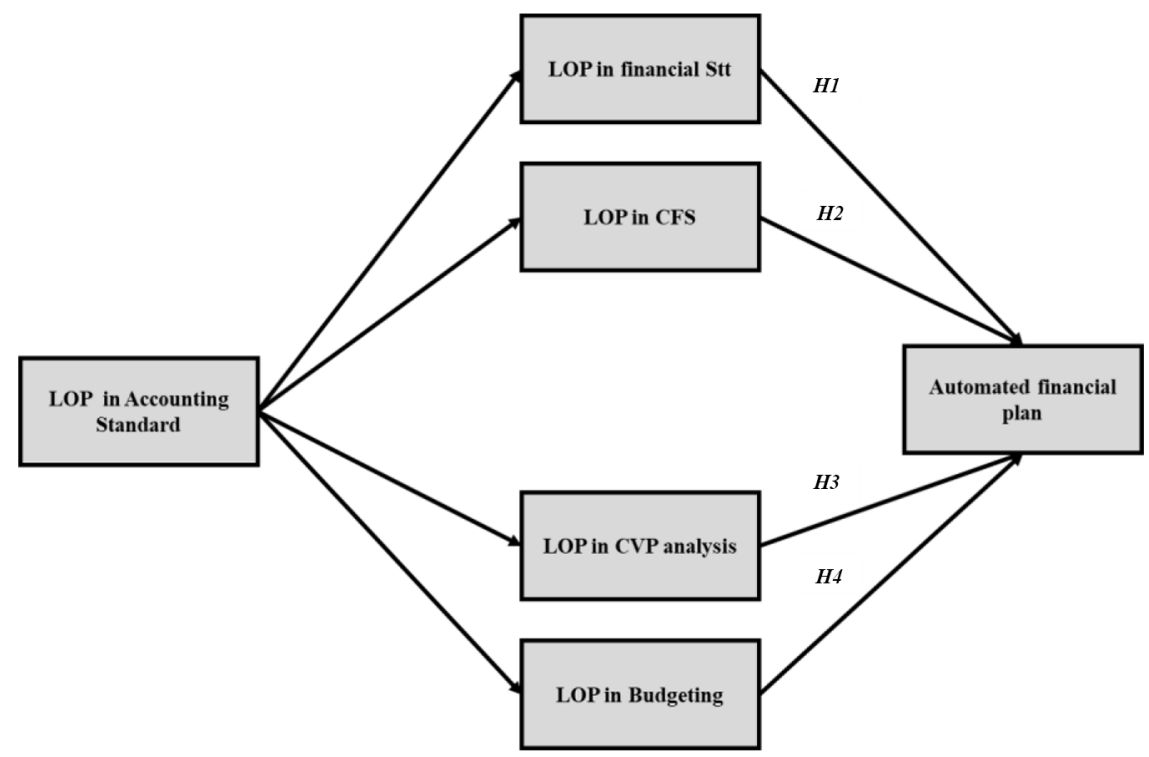

Source: Authors own elaboration

Figure 1. Theoretical model 


\section{JEET 1,1}

66

be considered accurate as the reliability of the expected construct score has increased. To evaluate the reliability and validity of the construct expected by SEM-PLS, composite reliabilities are shown in Table 1 . Cronbach's alpha assumption of parallel measures signifies a smaller bound estimation of internal consistency. Though, a clearer estimate can be achieved applying the composite reliability formula. The normal threshold point is 0.70 for an established measure (Nunnally, 1978).

\section{Results}

\subsection{Descriptive Statistics}

Table 2 shows the mean, minimum, maximum and standard deviation of adoption of AFP, the antecedent of LOP in accounting standards, followed by LOP in preparing financial statements, CFS, CVP analysis and budgeting.

Discriminant validity is the degree to which measures precisely distinct from any other constructs (Hair et al., 2010; Bagozzi and Phillips, 1982). Different construct measures should share some variance. Discriminant validity analysis may assist to validate issues of content validity the minute it is suspected when some measures, in fact, parallel to another concept (Ariño, 2003). Established discriminant validity provides to examine whether there are robust discrepancies between dissimilar constructs within connected measures (Kopcha et al., 2014). To analyze discriminant validity by using SEM-PLS, one should use the standard criteria. To use the standard criteria, each construct's average variance extracted (AVE), which is more eminent, should be related by its squared correlations with other constructs in the proposed model (Fornell and Larcker, 1981; Henseler et al., 2015). As shown in Table 3, the intended square root of the AVE exceeds the inter-correlations of the hypothesis with the other hypotheses in the model which warrant acceptable discriminant validity.

\begin{tabular}{lcccc}
\hline & Cronbach's alpha & rho_A & Composite reliability & $\begin{array}{c}\text { Average Variance } \\
\text { Extracted (AVE) }\end{array}$ \\
\hline AFP & 0.896 & 0.935 & 0.924 & 0.651 \\
LOP_AS & 0.924 & 0.925 & 0.946 & 0.815 \\
LOP_B & 0.931 & 0.934 & 0.956 & 0.878 \\
LOP_CFS & 0.935 & 0.935 & 0.951 & 0.795 \\
LOP_CVP & 0.916 & 0.919 & 0.947 & 0.761 \\
LOP_FS & 0.980 & 0.981 & 0.982 &
\end{tabular}

Source: Authors own elaboration based on the results of PLS analysis

Construct reliability and validity

\begin{tabular}{lcccr}
\hline Variables & Mean & Minimum & Maximum & SD \\
\hline Automated financial plan & 0.115 & -2.104 & 1.940 & 1.000 \\
LOP in accounting standards & 0.026 & -2.021 & 2.074 & 1.000 \\
LOP in preparing financial statements & 0.139 & -2.218 & 1.902 & 1.000 \\
LOP in preparing CFS & 0.117 & -2.077 & 1.905 & 1.000 \\
LOP in preparing CVP analysis & 0.010 & -1.833 & 1.853 & 1.000 \\
LOP in preparing budgeting & 0.009 & -1.841 & 1.858 & 1.000
\end{tabular}

Table 2.

LOP in preparing budgeting

Source: Authors own elaboration based on the results of PLS analysis 
Structural equation model evaluation is a multivariate statistical analysis which may perform to examine structural relationship as its investigation has included all the prescribed standards. The preliminary point for determining the structural model was to examine the determination coefficient $\left(R^{2}\right)$. The current research study, endogenous variable accomplishes which have $R^{2}$ value 0.762 (confirm substantial) which has further indicated that $76 \%$ of the variance in AFP can be described by antecedent as accounting standard for LOP in preparing financial statements(58\%), LOP in preparing CFSs $(64 \%)$, LOP in CVP analysis $(71 \%)$ and LOP in budgeting $(68 \%)$ (Table 4$)$.

\subsection{Hypotheses testing}

The variables of the current study were taken in SEM-PLS by applying bootstrapping method. The path-coefficient range is considered to be satisfactorily acceptable if it is greater than 0.1 points (Henseler et al., 2016).

The initial hypotheses tests were carried out without considering LOP in accounting standards as the antecedent for LOP in preparing financial statements, CFS, CVP analysis and budgeting) with AFP. "Table 5" represents the direct effect of independent variables on the dependent variable, AFP. LOP in financial statements has only supported which shows

\begin{tabular}{lcccccc}
\hline Variables & AFP & LOP_AS & LOP_B & LOP_CFS & LOP_CVP & LOP_FS \\
\hline AFP & 0.807 & & & & & \\
LOP_AS & 0.676 & 0.903 & & & & \\
LOP_B & 0.667 & 0.830 & 0.937 & & \\
LOP_CFS & 0.764 & 0.803 & 0.757 & 0.892 & 0.925 & 0.872 \\
LOP_CVP & 0.699 & 0.847 & 0.746 & 0.801 & 0.764 & 0.852 \\
LOP_FS & 0.869 & 0.764 & 0.703 & &
\end{tabular}

Source: Authors own elaboration based on the results of PLS analysis
Antecedent of lack of proficiency

\begin{tabular}{llc}
\hline Endogenous Construct & & Variance Explained $\left(\mathrm{R}^{2}\right)$ \\
\hline Exogenous Variables $\rightarrow$ & AFP & 0.762 \\
Endogenous (Automated & LOP_FS & 0.584 \\
financial plan - AFP) & LOP_CFS & 0.644 \\
& LOP_CVP & 0.717 \\
& LOP_B & 0.689
\end{tabular}

Source: Authors own elaboration based on the results of PLS analysis

Table 4. Variance explained

\begin{tabular}{lccr}
\hline Path & Path Coefficient & Standard Error & $t$-value \\
\hline LOP_FS $\rightarrow$ AFP & 0.000 & 0.075 & $* * * 10.178$ \\
LOP_CFS $\rightarrow$ AFP & 0.892 & 0.094 & 0.136 \\
LOP_CVP $\rightarrow$ AFP & 0.679 & 0.079 & 0.415 \\
LOP_B $\rightarrow$ AFP & 0.204 & 0.073 & 1.273
\end{tabular}

Note: Significance levels: $* * * p<0.001(t>3.33), * * p<0.01(t>2.33), * p<0.05(t>1.605)$ (based in onetailed test)

Table 5.

Path coefficients 


\section{JEET 1,1}

68

$P<0.001, t=10.178$. Whereas, LOP in CFS, LOP in CVP analysis and LOP in budgeting have $P<0.05, t=0.136 ; P<0.05, t=0.415$; and $P<0.05, t=1.273$ respectively were not supported with AFP.

Later, the hypotheses $H 1, H 2, H 3$ and $H 4$ were considered with antecedents (LOP in accounting standard) and assumed to have the effect either positively or negatively related between LOP in preparing financial statements, CFS, CVP analysis and budgeting) and the need for an AFP. It reveals that all four hypotheses were significant, which are depicted in "Table 6".

All the independent variables with the antecedent of LOP in accounting standards have a positive relationship with AFP, (LOP in preparing financial statements 0.000, CFS 0.000, CVP analysis 0.000 and budgeting 0.000 ).

The study result showed that LOP in preparing financial statements has a positive relationship with AFP where it was $P<0.001, t=17.885$. This result specifies that the antecedent of LOP in preparing financial statements has a positive impact on AFP. This has been pointed that there is a lack of student's proficiency in accounting standards and preparing financial statements among students among HEIs in Oman. Therefore, $H 1$ is supported.

The study result showed that LOP in preparing CFS has a positive relationship with AFP where it was $P<0.001, t=18.917$. This result specifies that the antecedent of LOP in preparing CFS has a positive impact on AFP. This has been pointed that there is a lack of student's proficiency in accounting standards and preparing CFS within students among HEIs in Oman. Therefore, $H 2$ is supported.

The study result showed that LOP in preparing CVP analysis has a positive relationship with AFP where it was $P<0.001, t=29.357$. This result specifies that the antecedent of LOP in preparing CVP analysis has a positive impact on AFP. This has been pointed that there is a lack of student's proficiency in accounting standards and preparing CVP analysis within students among HEIs in Oman. Therefore, H3 is supported.

The study result showed that LOP in preparing budgeting has a positive relationship with AFP where it was $P<0.001, t=23.901$. This result specifies that the antecedent of LOP in preparing budgeting has a positive impact on AFP. This has been pointed that there is a lack of student's proficiency in accounting standards and preparing budgeting within students among HEIs in Oman. Therefore, $H 4$ is also supported.

Therefore, all four results of the study have been supported which shows that all the factors have a significant influence on AFP.

\section{Discussion}

\subsection{LOP in preparing financial statements on automated financial plan}

The initial factor tested in the current study was the antecedent of LOP in preparing Financial Statements. Some of the research studies have recognized that LOP in preparing

Table 6.

Path coefficients

\begin{tabular}{llccr}
\hline Hypotheses & Path & Path coefficient & Standard error & $t$-value \\
\hline H1 & LOP_AS $\rightarrow$ LOP_FS $\rightarrow$ AFP & 0.000 & 0.043 & $* * * 17.885$ \\
$H 2$ & LOP_AS $\rightarrow$ LOP_CFS $\rightarrow$ AFP & 0.000 & 0.042 & $* * * 18.917$ \\
H3 & LOP_AS $\rightarrow$ LOP_CVP $\rightarrow$ AFP & 0.000 & 0.029 & $* * * 29.357$ \\
$H 4$ & LOP_AS $\rightarrow$ LOP_B $\rightarrow$ AFP & 0.000 & 0.035 & $* * * 23.901$
\end{tabular}

Note: Significance levels: ${ }^{* * *} p<0.001(t>3.33),{ }^{* *} p<0.01(t>2.33),{ }^{*} p<0.05(t>1.605)$ (based in onetailed test)

Source: Authors own elaboration based on the results of PLS analysis 
Financial statements is one of the significant factors that affect the AFP (King et al., 2020; Aleksieienko et al., 2020; Ferreras-Garcia et al., 2019; Easton et al., 2018; Abbott and Palatnik, 2018). LOP in preparing manual financial statements by accounting and non-accounting graduating students faces major constraints for their compulsory entrepreneurship course.

The result of the path-coefficient analysis revealed in Table 6 above shows a positive significant relationship between LOP in preparing financial statements and $\operatorname{AFP}(\beta=0.000$, $p<0.001)$. Thus, it can be concluded that the rational justification for attaining this effect for the 1st hypothesis, is that students LOP in preparing financial statements will increase the willingness to accept AFP by colleges and universities for the Course Entrepreneurship Creativity and Innovation.

\subsection{LOP in preparing cash flow statement on automated financial plan}

For the second factor antecedent of LOP in preparing CFS, the result finding shows that there is a positive relationship between LOP in preparing CFS and AFP. The result has in line with the proposed objectives of the present study which shows a positive and significant direction $(t=18.917, P<0.001)$. LOP in preparing a manual CFS by accounting and non-accounting graduating students faces major constraints for their compulsory entrepreneurship course. Likewise (Mavl, utova et al., 2019b) states that an AFP would include CFSs. Computations of cash flow should allow to avoid unexpected circumstances and assist planning for future periods. The central benefit of cash flow automation in an ICT environment is the opportunity to estimate different situations along with the opportunity to assess whether the investment in a proposed entrepreneurial project is successful or not, compared to alternative investment likelihoods. This research result is as per what has been set in the objectives of the present study. Hence the study can be evident that the majority of students were in the opinion that LOP in preparing CFS will significantly help to adopt AFP for the course entrepreneurship creativity and innovation.

\subsection{LOP in preparing cost volume profit analysis on automated financial plan}

The third factor, the antecedent of LOP in preparing CVP analysis, the result finding shows that there is a positive relationship between LOP in preparing CVP analysis and AFP. This finding shows that LOP in preparing CVP analysis has a positive impact on AFP. The result has in line with the proposed objectives of the present study, which shows that a positive and significant direction $(t=29.357, P<0.001)$ with AFP. This might be attributed to the fact that LOP in preparing CVP analysis among students who study the course entrepreneurship creativity and innovation.

Furthermore (Le et al., 2020) states that an AFP should include the detailed relationship of cost, volume (sales) and net income (net profit). Computation equilibriums point and payback period of the proposed project allows to project accurately and plan their financial needs at the initial stage. It helps to control and target sales in future periods. The central benefit of the CVP is to analyze the relationship of cost, volume and profit and to estimate different sales volume levels for the proposed entrepreneurial project. This research result is as per what has been set in the objectives of the present study. Hence the students were agreed that there is a significant relationship between LOP in preparing CVP analysis with AFP for the course entrepreneurship creativity and innovation.

\subsection{LOP in preparing budgeting on automated financial plan}

The fourth factor tested in the current study was the antecedent of LOP in preparing a budget. Some of the research studies have suggested that LOP in preparing a budget is one 
JEET
1,1

of the crucial factors that will affect AFP (Ponniah et al., 2020; Maziriri et al., 2018). Students LOP in preparing manual flexible or static budgeted, projected income statement, budgeted statement of financial statement and budgeted CFSs major constrain for their compulsory course, entrepreneurship creativity and innovation. AFP assists to prepare well-thought-out budget reports even for non-accounting students for their compulsory course, entrepreneurship creativity and innovation (Stetsiv et al., 2020; Jalbert, 2019).

The result of the path-coefficient analysis revealed in "Table 6 " above shows a positive significant relationship between LOP in preparing budgeting and AFP $(\beta=0.000$, $p<0.001)$. This has been supporting with the hypothesis tested in the present study, which specifies that students in colleges and universities to whom the course, entrepreneurship creativity and innovation, made compulsory tempt to adopt curriculum-based AFP for preparing financial budgeting for the course entrepreneurship creativity and innovation.

Thus, it can be concluded that the rational justification for attaining this effect for the fourth hypothesis, is that students LOP in preparing budgeting will increase the willingness to incorporate it to the AFP by colleges and universities for the compulsory, course entrepreneurship creativity and innovation.

Figure 2 represents the structural model, with antecedent effect on LOP and explained variances of the endogenous construct.

\section{Implications}

The research findings lead to several implications. The current study findings enrich existing theories and contribute to the entrepreneurship literature. Besides, this study further added a new discussion, i.e. student's antecedent of LOP in (preparing financial statements, CFS, CVP analysis and budgeting) toward AFP for the course entrepreneurship creativity and innovation within HEIs.

Figure 2.

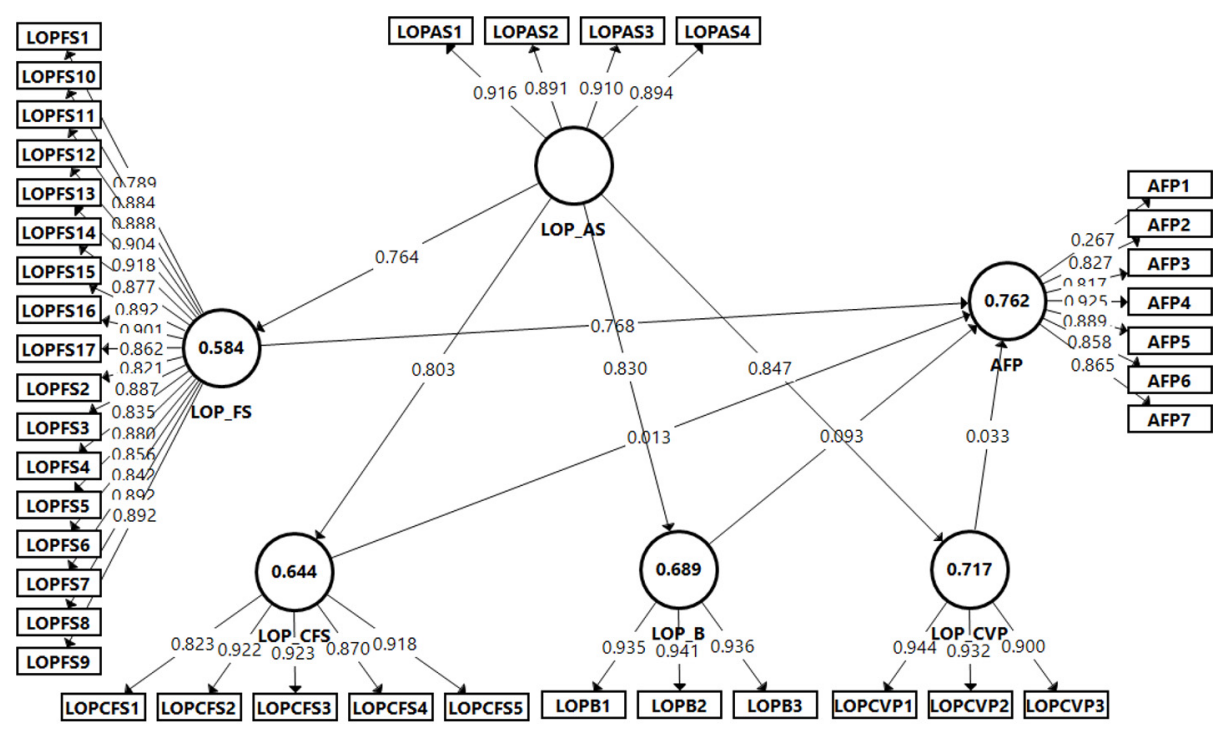

Source: Authors own elaboration based on the results of PLS analysis 
As there are no previous studies, as per the authors' knowledge, this study gives novelty in the current field of entrepreneurship student's perspectives. The study envisioned to gain public awareness among HEIs (including various colleges and universities) to adopt AFP in the course syllabus by colleges and universities not only in the form but also in substance. This study considered both accounting and nonaccounting students (bachelor/diploma) by giving them AFP for their compulsory course, entrepreneurship creativity and innovation. This may suggest HEIs in Oman to go for AFP in the present course, entrepreneurship creativity and innovation. This lack of proficiency may lead to revise or improve the current curriculum of HEIs and their regulatory frameworks to push universities and colleges to move toward AFP. Accordingly, the present study is a guide for considering AFP by universities and colleges to enrich the course, entrepreneurship creativity and innovation both for the students and teachers. The outcome of this study also benefits for the software vendors to develop customized AFP for entire universities and colleges in Oman. This however indicates that, once customized AFT is properly applied with applicable accounting concepts (accounting standards) which can be suitable for various universities and colleges in Oman that may be helpful to increase students' skills, knowledge and efficiency to prepare a fair financial plan for their proposed business plan. This will ease to predict (prepare) their proposed business plan profits with different sales revenue and will lead to encouraging them for future entrepreneurship start-ups. Thus, LOP in (preparing financial statements, CFS, CVP analysis and budgeting) towards curriculum-based AFP enhance the professional approach to implement for the course entrepreneurship creativity and innovation within HEIs in Oman. This can lead to attaining the best method of satisfying the interests of various stakeholders (such as students, teachers and financial institutions) who uses technology-enabled financial statements. This study may give a contribution to the statutory regulators and policymakers in general, HEIs, universities and colleges and government, to establish wise and timely policies related to include AFP in universities and its awareness among them.

\section{Conclusion}

In the era of The Fourth Industrial Revolution (IR 4.0), entrepreneurial education emphasizes the proficiency of students to use AFP. Hence, this study establishes an attempt to study students' antecedents of LOP proficiency in (preparing financial statements, CFS, CVP analysis and budgeting) towards adoption of AFP for the compulsory course, entrepreneurship creativity and innovation within HEIs in Oman. The study focuses on factors or antecedents of LOP that contribute to the successful implementation of AFP for the course entrepreneurship creativity and innovation. In respect to entrepreneurship education, all the major (both accounting or non-accounting graduates) should have a strong fundamental understanding of accounting concepts to prepare a financial and business plan. In Oman, the course, entrepreneurship creativity and innovation have been made compulsory for both accounting and non-accounting undergraduate (both for diploma and bachelor) students. Therefore, the present entrepreneurship education should have the proficiency of the ever-changing entrepreneurial environment and should include a balanced combination of technological and non-technical skills in accounting.

The current study has value, as it gives useful data for Oman entrepreneurship educators on how entrepreneurship course in emergent nation responds. Likewise, it gives important insights for entrepreneurship course educators in other developed and emerging countries, the essential to analyze what is taught, trained and learned in colleges and universities are 


\section{JEET 1,1}

up to date and meet the needs of all the students to whom the course, entrepreneurship creativity and innovation, made compulsory. The research findings confirmed that there is a positive and significant relationship between all the components, LOP in preparing financial statements, LOP in preparing CFS, LOP in preparing CVP analysis and LOP in preparing budgeting.

The present study has some limitations. It has taken a limited variable. In the future, the researchers can consider this limitation and examine further related variables. Further, the studies could extent on diploma students' practical knowledge of ICT in Oman to find out their opinions about preparing a business plan for the course entrepreneurship creativity and innovation.

\section{References}

Abbott, J.I. and Palatnik, B.R. (2018), "Students' perceptions of their first accounting class: implications for instructors", Accounting Education, Vol. 27 No. 1, pp. 72-93.

Abdullahi, S.R., Bello, S., Mukhtar, I.S. and Musa, M.H. (2017), "Cost-volume-profit analysis as a management tool for decision making in small business enterprise within Bayero university", IOSR Journal of Business and Management, Vol. 19 No. 2, pp. 40-45.

Ahmad, N.N., Ahmad, S. and Abdullah, W.M.T.W. (2018), "Sustaining SMEs through resources availability and cash management practices: an application of the partial least squares (PLS)", Global Business and Management Research, Vol. 10 No. 3, p. 24.

Ahmed, E.R., Alabdullah, T.T.Y., Thottoli, M.M. and Maryanti, E. (2020), "Does corporate governance predict firm profitability? An empirical study in Oman", The International Journal of Accounting and Business Society, Vol. 28 No. 1, pp. 127-143.

Ahrens, T. and Ferry, L. (2018), "Institutional entrepreneurship, practice memory, and cultural memory: choice and creativity in the pursuit of endogenous change of local authority budgeting", Management Accounting Research, Vol. 38, pp. 12-21.

Al Hussaini, A.N. (2019), "Exploring the relationship between entrepreneurship development and financial management expertise among the students: a study from Kuwait", Academy of Entrepreneurship Journal, Vol. 25, pp. 1-17.

Alabdullah, T.T.Y., Ahmed, E.R. and Muneerali, M. (2019), "Effect of board size and duality on corporate social responsibility: what has improved in corporate governance in Asia?", Journal of Accounting Science, Vol. 3 No. 2, pp. 121-135.

Aleksieienko, I.I. Leliuk, S.V. Poltinina, O.P. and Yushko, S.V. (2020), "Registration and financial statements preparation of business: syllabus of the academic discipline for students of all specialty of the first (bachelor's) level”, in Kharkov, I.I. (Ed.), KhNEU them. S. Kuznets, p. 12, available at: http://repository.hneu.edu.ua/handle/123456789/24152

Ali, H., Omar, E.N., Nasir, H.A. and Osman, M.R. (2018), "Financial literacy of entrepreneurs in the small and medium enterprises", Proceedings of the 2nd Advances in Business Research International Conference, Springer, Singapore, pp. 31-38.

Allen, C. (2020), "Six steps to starting a successful business", Marriott Student Review, Vol. 3 No. 4 , p. 7.

Ariño, A. (2003), "Measures of strategic alliance performance: an analysis of construct validity", Journal of International Business Studies, Vol. 34 No. 1, pp. 66-79.

Arpat, B., Yeşi 'L, Y. and Kocaalan, M.L. (2019), "A longitudinal study on the effect of entrepreneurship courses taught at the vocational colleges in Turkey on students' entrepreneurial tendency", Eastern Journal of European Studies, Vol. 10 No. 2.

Bagozzi, R.P. and Phillips, L.W. (1982), "Representing and testing organizational theories: a holistic construal”, Administrative Science Quarterly, Vol. 27 No. 3, pp. 459-489. 
Banerjee, R., Tarazi, J. and Akre, V. (2018), November). "Mobile app for cost-volume-profit analysis-an interdisciplinary student project for promoting active learning in managerial accounting and IT", 2018 Fifth HCT Information Technology Trends (ITT), IEEE, pp. 117-125.

Barclay, D.W. Higgins, C. and Thompson, R. (1995), “The partial least squares (PLS) approach to casual modeling: personal computer adoption and use as an illustration", Technol. Stud. Vol. 2 No. 2, pp. 285-309.

Barrow, C., Barrow, P. and Brown, R. (2018), The Business Plan Workbook: A Step-By-Step Guide to Creating and Developing a Successful Business, Kogan Page Publishers.

Bornman, M. and Wassermann, M. (2020), "Tax knowledge for the digital economy”, Journal of Economic and Financial Sciences, Vol. 13 No. 1, pp. 1-11.

Burgos, J.A.M., Kittler, M. and Walsh, M. (2020), "Bounded rationality, capital budgeting decisions and small business", Qualitative Research in Accounting and Management, Vol. 17 No. 2, pp. 293-318.

Cescon, F. and Grassetti, L. (2020), "Financial control and business strategy in start-up companies: an empirical analysis", Università degli studi di Udine, Dipartimento di scienze economiche e statistiche.

Chin, W.W. (1998), "The partial least squares approach to structural equation modeling", Modern Methods for Business Research, Vol. 295 No. 2, pp. 295-336.

Chin, W.W., Marcolin, B.L. and Newsted, P.R. (1996), "A partial least squares latent variable modeling approach for measuring interaction effects: results from a Monte Carlo simulation study and voice mail emotion/adoption study", Proceedings of the 17th International Conference on Information Systems, Cleveland, $\mathrm{OH}$, pp. 21-41.

Das, S.C. and Singh, R.K. (2018), "Accounting education in India and USA: a comparative study", Journal of Commerce and Accounting Research, Vol. 7 No. 1, pp. 54-64.

Donleavy, G.D., Poli, P.M., Conover, T.L., Albu, C.N., Dahawy, K., Iatridis, G., Kiaptikulwattana, P., Budsaratragoon, P., Klammer, T., Lai, S.C. and Trepat, J.N. (2018), "How numeracy mediates cash flow format preferences: a worldwide study", The International Journal of Management Education, Vol. 16 No. 2, pp. 180-192.

Easton, P.D., McAnally, M.L., Sommers, G.A. and Zhang, X.J. (2018), Financial Statement Analysis and Valuation, Cambridge Business Publishers, Boston, MA.

Fakhrurraji, A., Prasetyono, P. and Musyarofah, S. (2019), "The problem with state finance planning and budgeting in higher education”, Asia Pacific Fraud Journal, Vol. 4 No. 1, pp. 101-111.

Farrelly, A.L., Michel, M., Sheridan, P.M. and Giglio, G. (2018), "A faculty-student curriculum mapping process for the uniform CPA examination blueprints”, Academy of Business Research Journal, Vol. 2, pp. 64-82.

Ferreras-Garcia, R., Hernández-Lara, A.B. and Serradell-López, E. (2019), "Entrepreneurial competences in a higher education business plan course", Education + Training, Vol. 61 Nos 7/8, pp. 850-869.

Fordham, D.R. and Hamilton, C.W. (2019), "Accounting information technology in small businesses: an inquiry", Journal of Information Systems, Vol. 33 No. 2, pp. 63-75.

Fornell, C. and Larcker, D.F. (1981), "Structural equation models with unobservable variables and measurement error: Algebra and statistics", Journal of Marketing Research, Vol. 18 No. 3, pp. 382-388, doi: 10.2307/3150980, or available at: www.jstor.org/stable/3150980

Haenlein, M. and Kaplan, A.M. (2004), "A beginner's guide to partial least squares analysis", Understanding Statistics, Vol. 3 No. 4, pp. 283-297.

Hair, J.F., Black, W.C., Babin, B.J. and Anderson, R.E. (2010), Multivariate Data Analysis, 7th ed., Prentice Hall, Englewood Cliffs, NJ, available at: www.scirp.org/(S(i43dyn45teexjx455qlt3d2q))/ reference/ReferencesPapers.aspx?ReferenceID=1839925 


\section{JEET 1,1}

Henseler, J., Hubona, G. and Ray, P.A. (2016), "Using PLS path modeling in new technology research: updated guidelines”, Industrial Management and Data Systems, Vol. 116 No. 1, pp. 2-20.

Henseler, J., Ringle, C.M. and Sarstedt, M. (2015), "A new criterion for assessing discriminant validity in variance-based structural equation modeling”, Journal of the Academy of Marketing Science, Vol. 43 No. 1, pp. 115-135.

Huang, X. and Si, Y. (2019), "Exploration on the reform of accounting courses for non-accounting majors in economics and management”, 20195 th International Conference on Social Science and Higher Education (ICSSHE 2019), Atlantis Press, pp. 1094-1096.

Ishmuradova, I., Karamyshev, A., Lysanov, D., Isavnin, A. and Eremina, I. (2019), "Persectives of application of project budgeting in commercial organizations", 2019 12th International Conference on Developments in eSystems Engineering (DeSE), IEEE, pp. 370-373.

Jalbert, T. (2019), "A management focused tool for developing pro-forma financial statements", International Journal of Management and Marketing Research, Vol. 12 No. 1, pp. 61-86.

Karanović, B., Nikolić, G. and Karanović, G. (2019), "Examining financial management practices in the context of smart ICT use: recent evidence from Croatian entrepreneurs", Zagreb International Review of Economics and Business, Vol. 22 No. s1, pp. 107-123.

King, E.M. Deibel, M.G. Bulgrin, M.J. Skeen, A. and Kieke, S.N. (2020), "A business plan for the Fitzgerald institute”, Williams Honors College, Honors Research Projects, p. 1171.

Kopcha, T.J., Ottenbreit-Leftwich, A., Jung, J. and Baser, D. (2014), "Examining the TPACK framework through the convergent and discriminant validity of two measures", Computers and Education, Vol. 78, pp. 87-96.

Le, O.T.T., Tran, P.T.T., Tran, T.V. and Nguyen, C.V. (2020), "Application of cost-volume-profit analysis in decision-making by public universities in Vietnam", The Journal of Asian Finance, Economics and Business, Vol. 7 No. 6, pp. 305-316.

Lee, C.H. and Chiravuri, A. (2019), "Dealing with initial success versus failure in crowdfunding market", Internet Research, Vol. 29 No. 5, pp. 1190-1212.

Lee, C.S. and Tajudeen, F.P. (2020), "Impact of artificial intelligence on accounting: evidence from Malaysian organizations", Asian Journal of Business and Accounting, Vol. 13 No. 1.

McCaster, A.L. (2020), "Communicating the language of business to non-business learners", Doctoral dissertation, Faculty of the School of Education in partial fulfillment of the requirements for the degree Doctor of Education in the School of Education, Indiana University.

Mavl, utova, I., Krastinšs, M., Hermanis, J. and Lešinskis, K. (2019a), "Student-centered methods in entrepreneurship education to increase entrepreneurial intentions of students", Littera Scripta, Vol. 12 No. 2, pp. 49-66.

Mavl, utova, I. Lešinskis, K. Hermanis, J. and Krastinš, M. (2019b), "Development of entrepreneurial mindset and improvement of student's business idea viability through innovative teaching methods in higher education", STRATEGICA, p. 211.

Maziriri, E.T., Mapuranga, M. and Madinga, N.W. (2018), "Self-service banking and financial literacy as prognosticators of business performance among rural small and medium-sized enterprises in Zimbabwe", The Southern African Journal of Entrepreneurship and Small Business Management, Vol. 10 No. 1, pp. 1-10.

Muneerali, M.T. (2020), "Impact of accounting software among SMEs accountants in Oman", Financial Markets, Institutions and Risks, Vol. 4 No. 2, pp. 25-33.

Nasu, V.H., Nogueira, D.R., Albertin, E.A. and Marques, C. (2019), "Too big to ignore: Lato sensu business students' perceptions on an accounting big data case", Future Studies Research Journal: Trends and Strategies, Vol. 11 No. 3.

Nso, M.A. (2020), "Fundraising and budgeting practices for SMEs", Asian Journal of Interdisciplinary Research, Vol. 3 No. 1, pp. 151-161.

Nunnally, J.C. (1978), Psychometric Theory, McGraw-Hill, New York, NY. 
Okpala, K.E. and Osanebi, C.O. (2020), "Cost volume profit analysis and profit planning in manufacturing SMEs in Nigeria", Asia-Pacific Management Accounting Journal, Vol. 15 No. 2, pp. 207-240.

Ponniah, K., Thannimalai, T.M. and Nawastheen, F.M. (2020), "Multigrading classes application and teacher's preparation in low enrolment schools in Malaysia", International Journal of Psychosocial Rehabilitation, Vol. 24 No. 6, pp. 7122-7135.

Shamsudin, A., Pauzi, N.F.M., Karim, M.S., Roslan, N. and Ahmad, K. (2020), "Utilising SATA in measuring students' understanding of financial statements: a survey among non-accounting students”, Jurnal Dinamika Akuntansi, Vol. 12 No. 1, pp. 24-33.

Stetsiv, I. Stetsiv, I. and Havras, D. (2020), "Problems of automation of economic work at enterprise", Збірник наукових праць $\Lambda$ ОГО $\Sigma$, pp. 24-27.

Stice, J.D., Stice, E.K., Cottrell, D.M. and Stice, D. (2019), "Teaching operating cash flow: one matrix for analysis - two methods for presentation", Advances in Accounting Education: Teaching and Curriculum Innovations, Emerald Publishing.

Sulindawati, N.L.G.E. and Meitriana, M.A. (2019), "An analysis of the reliability of a teaching model for presenting a computer-based cash flow report”, KnE Social Sciences, pp. 103-114.

Thottoli, M.M. (2020), "Knowledge and use of accounting software: evidence from Oman", Journal of Industry-University Collaboration.

Thottoli, M.M. (2021), "Impact of information communication technology competency among auditing professionals", Accounting. Analysis. Auditing, Vol. 8 No. 2, pp. 38-47.

Thottoli, M.M. and Thomas, K.V. (2020), "Characteristics of information communication technology and audit practices: evidence from India", VINE Journal of Information and Knowledge Management Systems.

Thottoli, M.M., Thomas, K.V. and Ahmed, E.R. (2019a), "Qualitative analysis on information communication technology and auditing practices of accounting professionals", Journal of Information and Computational Science, Vol. 9 No. 9.

Thottoli, M.M. Thomas, K.V. and Ahmed, E.R. (2019b), "Adoption of audit software by audit firms: a qualitative study”, Journal of Information and Computational Science, Vol. 9 No. 9, pp. 768-776.

Thottoli, M.M., Thomas, K.V. and Ahmed, E.R. (2019c), "Examining the impact of information communication technology on auditing professionals: a quantitative study", Journal of Advanced Research in Dynamical and Control Systems, Vol. 11 No. 12-SPECIAL ISSUE, pp. 476-488.

Tipu, S.A.A. (2019), "Business plan competitions in developed and emerging economies", Journal of Entrepreneurship in Emerging Economies, Vol. 11 No. 1, pp. 81-97.

Widodo, S., Wiardi, A.H. and Prabowo, T.D. (2019), "The antecedent of regional financial report quality", AFEBI Management and Business Review, Vol. 4 No. 1, pp. 38-47.

Zadeh, A.H., Sengupta, A. and Schultz, T. (2020), "Enhancing ERP learning outcomes through Microsoft dynamics", Journal of Information Systems Education, Vol. 31 No. 2, pp. 83-95.

\section{Further reading}

Bandera, C., Collins, R. and Passerini, K. (2018), "Risky business: experiential learning, information and communications technology, and risk-taking attitudes in entrepreneurship education", The International Journal of Management Education, Vol. 16 No. 2, pp. 224-238.

Brink, W.D. and Stoel, M.D. (2019), "Analytics knowledge, skills, and abilities for accounting graduates", Advances in Accounting Education: Teaching and Curriculum Innovations, Emerald Publishing.

Byun, C.G., Sung, C.S., Park, J.Y. and Choi, D.S. (2018), "A study on the effectiveness of entrepreneurship education programs in higher education institutions: a case study of Korean 


\section{JEET 1,1}

graduate programs", Journal of Open Innovation: Technology, Market, and Complexity, Vol. 4 No. 3, p. 26 .

Gazil, O., Gosselin, M., Tanguay-Rioux, F., Farand, P. and Tavares, J.R. (2019), "Simulating dynamically: a longitudinal and practical simulation approach for students", Computer Applications in Engineering Education, Vol. 27 No. 6, pp. 1531-1543.

George, D. and Mallery, M. (2003), SPSS for Windows Step by Step: A Simple Guide and Reference, 11.0 update (4th ed.), Allyn \& Bacon, Boston.

Howell, R., van Beers, C. and Doorn, N. (2018), "Value capture and value creation: the role of information technology in business models for frugal innovations in Africa", Technological Forecasting and Social Change, Vol. 131, pp. 227-239.

Khan, S.J.M. and Anuar, A.R. (2018), "Access to finance: exploring barriers to entrepreneurship development in SMEs", Global Entrepreneurship and New Venture Creation in the Sharing Economy, IGI Global, pp. 92-111.

König, M., Ungerer, C. and Baltes, G. (2018), "The semantics of entrepreneurial learning in new technology-based firms”, Technology Entrepreneurship, Springer, Cham, pp. 3-20.

Lugovsky, D. and Kuter, M. (2019), "Accounting policies, accounting estimates and its role in the preparation of fair financial statements in digital economy", International Conference on Integrated Science, Springer, Cham, pp. 165-176.

Nunnally, S.W. (1980), Construction Methods and Management [by] SW Nunnally, Prentice-Hall.

Omitogun, A. and Al-Adeem, K. (2019), "Auditors' perceptions of and competencies in big data and data analytics: an empirical investigation", International Journal of Computer Auditing, Vol. 1 No. 1, pp. 92-113.

Paolone, F., Sardi, A., Sorano, E. and Ferraris, A. (2020), "Integrated processing of sustainability accounting reports: a multi-utility company case study", Meditari Accountancy Research.

Rathore, G.S., Singh, B., Kumar, S., Rai, R. and Kumar, K. (2019), "Business prospects for entrepreneurs in skill based online education", SMS Journal of Entrepreneurship and Innovation, Vol. 6 No. 1, pp. 80-95.

Sembiring, A.C., Tampubolon, J., Sitanggang, D. and Turnip, M. (2019), "Improvement of inventory system using first in first out (FIFO) method", Journal of Physics: Conference Series, Vol. 1361 No. 1, p. 012070.

Wu, Y.J., Yuan, C.H. and Pan, C.I. (2018), "Entrepreneurship education: an experimental study with information and communication technology", Sustainability, Vol. 10 No. 3, p. 691.

\section{Corresponding author}

Mohammed Muneerali Thottoli can be contacted at: muneerali@unizwa.edu.om

For instructions on how to order reprints of this article, please visit our website:

www.emeraldgrouppublishing.com/licensing/reprints.htm

Or contact us for further details: permissions@emeraldinsight.com 